ISSN1027-5495. Functional Materials, 23, No.2 (2016), p. 255-260

doi:http://dx.doi.org/10.15407/fm23.02.255

(C) 2016 - STC “Institute for Single Crystals"

\title{
A study of effect of injection molding process parameters on the impact performance of plastic product fabricated by fine fillers filled LDPE
}

\author{
Hua Cai, Min Zeng \\ Department of Mechanical Engineering, Nanjing Polytechnic Institute, \\ Jiangsu, 210048, P.R. China
}

Received October 11,215

\begin{abstract}
This study analyzed the major injection molding process parameters that affect the impact performance of low-density polyethylene(LDPE) by orthogonal experiment method. Response surface methodology was proposed to analyze the significant influence factors, and then determined optimal parameters setting of injection molding process. The results show that melting temperature and packing time are the two significant factors influence the impact performance of plastic product. Logical process parameters combinations of melting temperature, packing time and filling time are achieved by further analysis using response surface methodology. By using the optimal parameters, the arrangement of the fillers is improved, as a result, the impact performance of the filler composite is enhanced.

Keywords: injection molding process parameters, impact performance, orthogonal experiment, response surface methodology
\end{abstract}

Анализируются основные параметры процесса литья под давлением, которые влияют на характеристики полиэтилена низкого давления (ПНД) методом прямого эксперимента. Предложена методология поверхности отклика для анализа важнейших влияющих факторов, после чего определены оптимальные наборы параметров процесса литья под давлением. Результаты показывают, что температура плавления и время упаковки являются важнейшими фракторами, влияющими на характеристики получаемого пластика. Логичные комбинации параметров - температуры плавления, времени упаковки и времени заполнения - получены путем дальнейшего анализа с использованием методологии поверхности отклика. Используя оптимальные параметры, улучшено распределение наполнителя, в результате получены улучшенные характеристики композита с наполнителем.

Дослідження впливу параметрів процесу лиття під тиском на характеристики пластика, отриманого з поліетилену низького тиску 3 дрібнодисперсним наповнювачем. Хуа Цай, Мінь Цзен

Проаналізовано основні параметри процессу лиття під тиском, які впливають на характеристики поліетилену низького тиску (ПНТ) методом прямого експерименту. Запропоновано методологію поверхні відгуку для аналізу найбільш релевантних факторів, після чого визначено оптимальні набори параметрів процессу лиття під тиском. Результати показують, що температура плавлення та час пакування є найважливішими факторами, що визначають характеристики отримуваного пластика. Логічні комбінації параметрів температури плавлення, часу пакування та часу наповнювання - отримано шляхом подальшого аналізу із застосуванням методології поверхні відгуку. Використовуючи оптимальні параметри, досягнуто кращий розподіл наповнювача, і в результаті отримано покращені характеристики композиту з наповнювачем. 


\section{Introduction}

An expansion of the application of polymer has evolved through the development of industrialization. More and more functions are among the important requirements. Some methods of fabricating new functional materials have been presented duo to obtain this type of materials, which includes filled composites, fiber reinforced composites, intelligent composites and etc. Filling modification is an important method of plastic modification, which can not only decrease the cost, but also evidently improve or enhance varieties of performance of the plastic products, endow materials new characteristics, and expend its application areas. The materials could possess different special performances, including mechanical properties, thermo stability, resistance high electric field, dielectric, magnetic dielectric and etc. by adding varieties of fine fillers [1-4]. During the injection molding process, different parameters setting of injection molding process will have direct and import effect on the quality of the plastic product [5-9].

This paper majorly studies the impact performance under different process parameters of the fine filler added low density polyethylene (LDPE). When injection molding process parameters were different, the impact performance of the products are change. Furthermore, find out the best parameters by orthogonal experiment method and response surface methodology.

\section{Experimental}

\subsection{Specimen design}

The experiment specimen is molded by an injection mold, which is a two-cavity mold with single parting surface and edge gates. Figure 1 shows the configurations of the experiment specimen and its runners. The gate is located in two testing clamp ends, the runner cross section is semicircle, and the cold well is "Z" type.

\subsection{Simulation analysis}

Software Moldflow was used to simulate and analyze the molding process of the specimen[10], in which the injection temperature was set to $180^{\circ} \mathrm{C}$ and the mold temperature was set to $50^{\circ} \mathrm{C}$. Simulation analysis chart of the filling time was shown in Fig.2. It shows that, the center of the experiment specimen is filled at the last, all colors are distributed symmetrically and with no color missed, the best filling time of the mold process is $2.334 \mathrm{~S}$. Simulation analysis chart of the cooling time was shown in Fig. 3. It shows that , the total cooling time is $30.78 \mathrm{~S}$, and the last place finish cooling is at the center of the spruce.

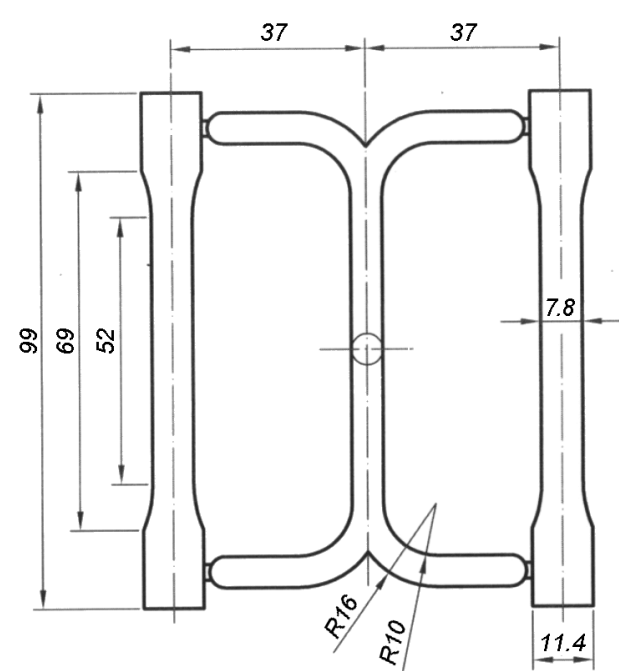

Fig. 1. Configurations of the experiment specimen and its runners

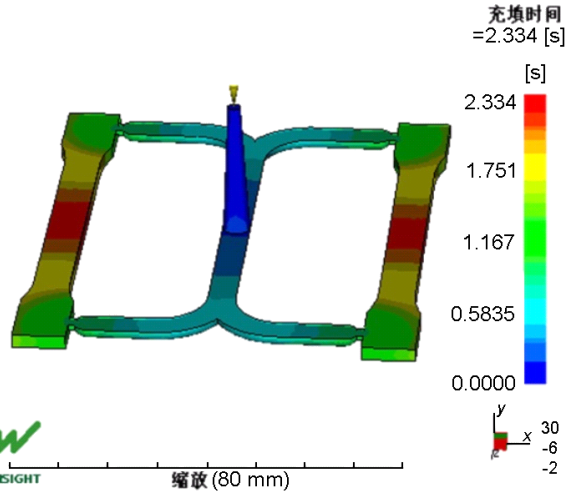

Fig. 2. Simulation analysis chart of the filling time

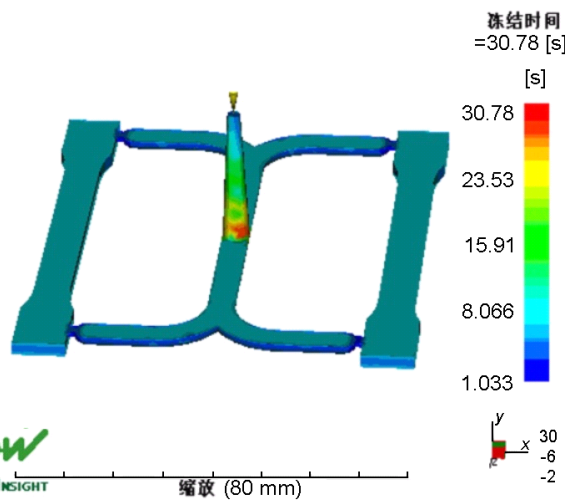

Fig. 3. Simulation analysis chart of the cooling time

\subsection{Materials and equipments}

A commercial low density polyethylene made in the polyolefin company (Singapore) pte. Ltd, and 200 meshes short fiber made in Hangzhou Gaoke composites Co., Ltd were used in this study. Volume content of the filler was 5\%. Mechanical blending machine was used to mix the raw materials. The model of the injection molding machine used to produce the specimen was 
Haitian SZ-980. Plastic ball indentation hardness tester was used to do the impact strength test, in which the pressure was $132 \mathrm{~N}$, pressure head diameter was $5 \mathrm{~mm}$, lasting time was $40 \mathrm{~s}$. FEI Quanta 250 scanning electron microscopy was used to observe the micro morphology of the specimen.

\subsection{Experimental parameter}

The major process parameters that affect the properties of the product is melting temperature, filling time and packing time. According to the structure of the simulation analysis, extend the experimental level one-level both up and down, in order to form 3 levels 3 factors, and the specific parameters were shown in table 1 .

Table 1. Injection molding process parameters levels table

\begin{tabular}{|c|c|c|c|}
\hline levels & $\begin{array}{c}\text { Packing } \\
\text { time (S) }\end{array}$ & $\begin{array}{c}\text { Filling } \\
\text { time (S) }\end{array}$ & $\begin{array}{c}\text { Tempera- } \\
\text { ture, }{ }^{\circ} \mathrm{C}\end{array}$ \\
\hline 1 & 20 & 2 & 160 \\
\hline 2 & 30 & 3 & 180 \\
\hline 3 & 40 & 4 & 200 \\
\hline
\end{tabular}

\section{Results and discussion}

\subsection{The orthogonal experiment method}

The orthogonal experiment method was used to experimental analyze the combination of each process parameters [11,12], in order to find the factor which has more effect on the impact performance, and then obtain the better process parameters combination for larger impact strength. Equivalent level orthogonal table was designed for this experiment. There are 3 factors and 3 levels, in total 9 times different combinations of process parameters. In order to validate error in statistical analysis, add an empty column, in total 4 columns and 3 rows, and an orthogonal array $\mathrm{L}_{9}\left(3^{4}\right)$ was used in this investment. To carry out experiments based on 9 different combinations of the process parameters. The arrangement of experiments and the results was shown in table 2 .

The experimental results shows that, factors affecting the most was melting temperature, the second is the packing time. The dispersion of the empty column was less than the dispersion of the other two parameters, the error is in the allowable range. The optimal injection molding process parameters obtained based on the orthogonal experiment method was scheme 8 , but the test value is smaller than scheme 3 , which is not the maximum in the whole experi- ment. Other methods should be used to do further analysis as the result is not comprehensive.

\subsection{Response surface methodology}

For the sake of acquiring better injection molding processing parameters, response surface methodology was used to further process the experimental data [13-14]. The factor of filling time was not considered during developing the model as it has the least effect on impact performance by means of orthogonal analyzing. Quadratic response approximation function was shown in equation (1):

$$
y=a_{0}+\sum_{i=1}^{n} a_{i} x_{i}+\sum_{i=1}^{n} a_{i i} x_{i}^{2}+\sum_{i=1}^{n-1} \sum_{j=i+1}^{n} a_{i j} x_{i} x_{j}
$$

Here: $n$ is the number of design variables; $a_{0}$ is undetermined coefficients of constant term; $\alpha_{i}$ is undetermined coefficient of first-order term; $a_{i j}$, $\mathrm{a}_{\mathrm{ij}}$ are undetermined coefficients of quadratic term.

In this equation, $x_{1}, x_{2}$ are first-order terms, $x_{1}^{2}, x_{2}^{2}, x_{1} x_{2}$ are quadratic terms, set $X_{1}=x_{1}$ , $X_{2}=x_{2}, \quad X_{3}=x_{1}^{2}, \quad X_{4}=x_{2}^{2}, \quad X_{5}=x_{1} x_{2}$, $\beta_{0}=a_{0}, \beta_{1}=a_{1}, \beta_{2}=a_{2}, \beta_{3}=a_{11}, \beta_{4}=a_{22}$ , $\beta_{5}=a_{12}$, equation (1) can be transformed into pro forma multiple linear function, showed in equation (2):

$$
\begin{gathered}
y=\beta_{0}+\beta_{1} X_{1}+\beta_{2} X_{2}+\ldots+\beta_{n} X_{n}= \\
=\beta_{0}+\sum_{i=1}^{n} \beta_{i} X_{i}
\end{gathered}
$$

The sum of squared residuals between the value of response surface function and experimental value can be expressed as equation (3):

$$
\theta=\sum_{i=1}^{n}\left(y_{i}-y_{i}^{\prime \prime}\right)^{2}
$$

According to the principle of least square method, there comes equation (4), in which $\theta$ has the smallest value, in order to make all the experimental point data at the closest place to the response surface.

$$
\left\{\begin{array}{c}
\frac{\partial \theta}{\partial \beta_{0}}=-2 \sum_{i=1}^{n}\left(y_{i}-\beta_{0}-\beta_{1} X_{1 i}-\cdots-\beta_{m} X_{m i}\right)=0 \\
\frac{\partial \theta}{\partial \beta_{1}}=-2 \sum_{i=1}^{n} x_{1 i}\left(y_{i}-\beta_{0}-\beta_{1} X_{1 i}-\cdots-\beta_{m} X_{m i}\right)=0 \\
\vdots \\
\frac{\partial \theta}{\partial \beta_{m}}=-2 \sum_{i=1}^{n} x_{m i}\left(y_{i}-\beta_{0}-\beta_{1} X_{1 i}-\cdots-\beta_{m} X_{m i}\right)=0
\end{array}\right.
$$

There are 5 parameters in equation (4), so $m=5$; the times of tests is 9 , so $n=9$, equation (4) can be transformed into a normal equation as follows: 


$$
\left[\begin{array}{cccccc}
9 & \sum_{i=1}^{9} X_{1 i} & \sum_{i=1}^{9} X_{2 i} & \sum_{i=1}^{9} X_{3 i} & \sum_{i=1}^{9} X_{4 i} & \sum_{i=1}^{9} X_{5 i} \\
\sum_{i=1}^{9} X_{1 i} & \sum_{i=1}^{9} X_{1 i}^{2} & \sum_{i=1}^{9} X_{1 i} X_{2 i} & \sum_{i=1}^{9} X_{1 i} X_{3 i} & \sum_{i=1}^{9} X_{1 i} X_{4 i} & \sum_{i=1}^{9} X_{1 i} X_{5 i} \\
\sum_{i=1}^{9} X_{2 i} & \sum_{i=1}^{9} X_{2 i} X_{1 i} & \sum_{i=1}^{9} X_{2 i}^{2} & \sum_{i=1}^{9} X_{2 i} X_{3 i} & \sum_{i=1}^{9} X_{2 i} X_{4 i} & \sum_{i=1}^{9} X_{2 i} X_{5 i} \\
\sum_{i=1}^{9} X_{3 i} & \sum_{i=1}^{9} X_{3 i} X_{1 i} & \sum_{i=1}^{9} X_{3 i} X_{2 i} & \sum_{i=1}^{9} X_{3 i}^{2} & \sum_{i=1}^{9} X_{3 i} X_{4 i} & \sum_{i=1}^{9} X_{3 i} X_{5 i} \\
\sum_{i=1}^{9} X_{4 i} & \sum_{i=1}^{9} X_{4 i} X_{1 i} & \sum_{i=1}^{9} X_{4 i} X_{2 i} & \sum_{i=1}^{9} X_{4 i} X_{3 i} & \sum_{i=1}^{9} X_{4 i}^{2} & \sum_{i=1}^{9} X_{4 i} X_{5 i} \\
\sum_{i=1}^{9} X_{5 i} & \sum_{i=1}^{9} X_{5 i} X_{1 i} & \sum_{i=1}^{9} X_{5 i} X_{2 i} & \sum_{i=1}^{9} X_{5 i} X_{3 i} & \sum_{i=1}^{9} X_{5 i} X_{4 i} & \sum_{i=1}^{9} X_{5 i}^{2}
\end{array}\right] \cdot\left[\begin{array}{c}
\sum_{i=1}^{9} y_{i} \\
\beta_{0} \\
\beta_{2} \\
\beta_{3} \\
\beta_{4} \\
\beta_{5}
\end{array}\right]=\left[\begin{array}{l}
\sum_{i=1}^{9} X_{1 i} y_{i} \\
9 \\
\sum_{i=1} X_{2 i} y_{i} \\
\sum_{i=1}^{9} X_{3 i} y_{i} \\
\sum_{i=1}^{9} X_{4 i} y_{i} \\
\sum_{i=1}^{9} X_{5 i} y_{i}
\end{array}\right]
$$

To further simplify the calculation, set

$$
x_{1 i}=\frac{x_{a i}-30}{10}, x_{2 i}=\frac{x_{c i}-180}{20}
$$

Here $x_{a i}, x_{c i}$ are the packing time and injection molding parameters during the experiment.

Experimental data can be further consolidated according to equation (6), the statistics of major data was shown in table 3 .

Take the statistics data into the formula (5), thus the equation can be consolidated as follows:

$$
\left[\begin{array}{cccccc}
9 & 0 & 0 & 6 & 6 & 0 \\
0 & 6 & 0 & 0 & 0 & 0 \\
0 & 0 & 6 & 0 & -7 & 0 \\
6 & 0 & 0 & 6 & 4 & 0 \\
6 & 0 & -7 & 4 & 6 & 0 \\
0 & 0 & 0 & 0 & 0 & 4
\end{array}\right] \bullet\left[\begin{array}{c}
\beta_{0} \\
\beta_{1} \\
\beta_{2} \\
\beta_{3} \\
\beta_{4} \\
\beta_{5}
\end{array}\right]=\left[\begin{array}{c}
70 \\
0.08 \\
-0.6 \\
47.1 \\
45.3 \\
0.03
\end{array}\right]
$$

Solution of this equation $\left(\beta_{0}, \beta_{1}, \beta_{2}, \beta_{3}, \beta_{4}, \beta_{5}\right)$ is $(7.4,0.013,0.3,0.22,0.345,0.01)$. Equation(8) as follows can be obtained by taking these data into equation (2):

$$
\begin{aligned}
y=7.4 & +0.013 X_{1}+0.3 X_{2}+0.22 X_{3}+ \\
& +0.345 X_{4}+0.01 X_{n}
\end{aligned}
$$

Full scale equation was shown in equation (9)

$$
\begin{gathered}
y=7.4+0.013 x_{1}+0.3 x_{2}+0.22 x_{1}^{2}+ \\
+0.345 x_{2}^{2}+0.01 x_{1} x_{2}
\end{gathered}
$$

In order to obtain the best value of packing time and melting temperature, solve the partial derivative of $x_{1}, x_{2}$ in equation 9). Consequently, the result was got, which is when $\mathrm{y}$ is maximum, $x_{1}, x_{2}$ in the function becomes $-0.013,-0.44$ respectively. The best value of packing time and melting temperature was carried out, which was $29.87 \mathrm{~S}, 171.2{ }^{\circ} \mathrm{C}$ respectively by taking the values of $x_{1}, x_{2}$ into equation (6) .

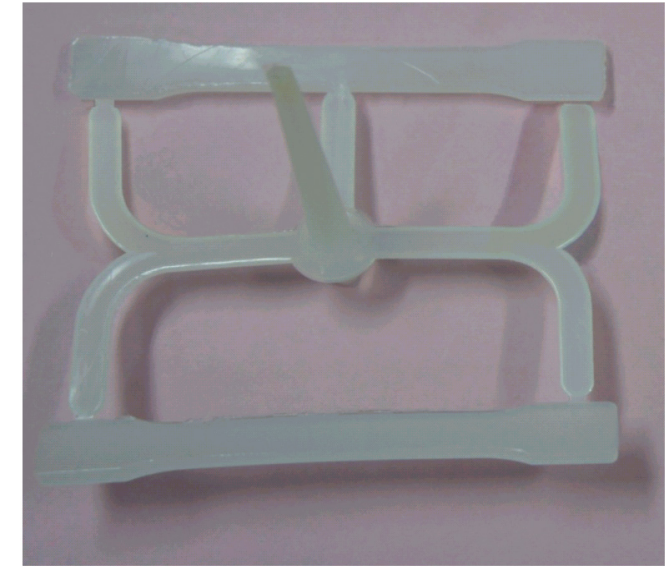

Fig.(4). Experimental specimen

\subsection{Experimental verification}

The result obtained through the orthogonal experiment method shows that filling time has the least influence on the impact performance among the three products. The products can be filled in a short time as the volume of theirs are small. So, in the verification scheme, the filling time was set to be $2.5 \mathrm{~S}$ refer to the result of simulation analysis, packing time and melting temperature was set to be $29.87 \mathrm{~S}, 171.2{ }^{\circ} \mathrm{C}$ respectively based on the analysis result done by response surface methodology, and keep the other parameters invariant. The verification specimen was shown in Fig.4, which impact strength is $8.62 \mathrm{~J} / \mathrm{mm}^{2}$, the result is better than that of the initial test scheme of all kinds of test results.

The parameters in tested scheme have the most similarity with those in optimal scheme, and the impact strength in testing scheme has the biggest difference with that in scheme 6 . For further analyzing the effect of the process parameters on impact performance, the micro morphology was used to observe the micro mor- 
Hua Cai,Min Zeng / A study of effect of injection molding process ...

Table 2 The arrangement of experiments and the results

\begin{tabular}{|c|c|c|c|c|c|}
\hline Experimental No. & $\begin{array}{c}\text { A } \\
\text { (packing } \\
\text { time) }\end{array}$ & $\begin{array}{l}\text { Empty } \\
\text { column }\end{array}$ & $\begin{array}{c}\text { B } \\
\text { (filling time) }\end{array}$ & $\begin{array}{c}\mathrm{C} \\
\text { (melting } \\
\text { temperature) }\end{array}$ & Impact strength \\
\hline 1 & 1 & 1 & 1 & 1 & 7.72 \\
\hline 2 & 1 & 2 & 2 & 3 & 7.35 \\
\hline 3 & 1 & 3 & 3 & 2 & 8.43 \\
\hline 4 & 2 & 1 & 2 & 2 & 7.94 \\
\hline 5 & 2 & 2 & 3 & 1 & 7.44 \\
\hline 6 & 2 & 3 & 1 & 3 & 7.52 \\
\hline 7 & 3 & 1 & 3 & 3 & 7.46 \\
\hline 8 & 3 & 2 & 1 & 2 & 8.32 \\
\hline 9 & 3 & 3 & 2 & 1 & 7.8 \\
\hline K1 & 23.5 & 23.12 & 23.56 & 22.96 & \\
\hline $\mathrm{K} 2$ & 22.9 & 23.11 & 23.09 & 24.69 & \\
\hline K3 & 23.58 & 23.76 & 23.33 & 22.33 & \\
\hline $\mathrm{k} 1$ & 7.83 & 7.71 & 7.85 & 7.65 & \\
\hline $\mathrm{k} 2$ & 7.63 & 7.70 & 7.70 & 8.23 & \\
\hline k3 & 7.86 & 7.92 & 7.78 & 7.44 & \\
\hline dispersion(R) & 0.23 & 0.22 & 0.16 & 0.79 & \\
\hline Factors major $\rightarrow$ secondary & \multicolumn{5}{|c|}{$\mathrm{C}>\mathrm{A}>$ Empty column $>\mathrm{B}$} \\
\hline Optimal solution & 3 & & 1 & 2 & \\
\hline
\end{tabular}

Table 3 Statistics sheet of quadratic response analysis data

\begin{tabular}{|c|c|c|c|c|c|c|c|c|c|c|c|}
\hline Parameter & $\mathrm{X}_{1}$ & $\mathrm{X}_{2}$ & $\mathrm{X}_{3}$ & $\mathrm{X}_{4}$ & $\mathrm{X}_{5}$ & $\mathrm{y}$ & $\mathrm{X}_{1} \mathrm{y}$ & $\mathrm{X}_{2} \mathrm{y}$ & $\mathrm{X}_{3} \mathrm{y}_{4}$ & $\mathrm{X}_{4} \mathrm{y}$ & $\mathrm{X}_{5} \mathrm{y}$ \\
\hline 1 & -1 & -1 & 1 & 1 & 1 & 7.72 & -7.7 & -7.7 & 7.72 & 7.72 & 7.72 \\
\hline 2 & -1 & 1 & 1 & 1 & -1 & 7.35 & -7.4 & 7.35 & 7.35 & 7.35 & -7.4 \\
\hline 3 & -1 & 0 & 1 & 0 & 0 & 8.43 & -8.4 & 0 & 8.43 & 0 & 0 \\
\hline 4 & 0 & 0 & 0 & 0 & 0 & 7.94 & 0 & 0 & 0 & 0 & 0 \\
\hline 5 & 0 & -1 & 0 & 1 & 0 & 7.44 & 0 & -7.4 & 0 & 7.44 & 0 \\
\hline 6 & 0 & 1 & 0 & 1 & 0 & 7.52 & 0 & 7.52 & 0 & 7.52 & 0 \\
\hline 7 & 1 & 1 & 1 & 1 & 1 & 7.46 & 7.46 & 7.46 & 7.46 & 7.46 & 7.46 \\
\hline 8 & 1 & 0 & 1 & 0 & 0 & 8.32 & 8.32 & 0 & 8.32 & 0 & 0 \\
\hline 9 & 1 & -1 & 1 & 1 & -1 & 7.8 & 7.8 & -7.8 & 7.8 & 7.8 & -7.8 \\
\hline \hline & 0 & 0 & 6 & 6 & 0 & 70 & 0.08 & -0.6 & 47.1 & 45.3 & 0.03 \\
\hline
\end{tabular}




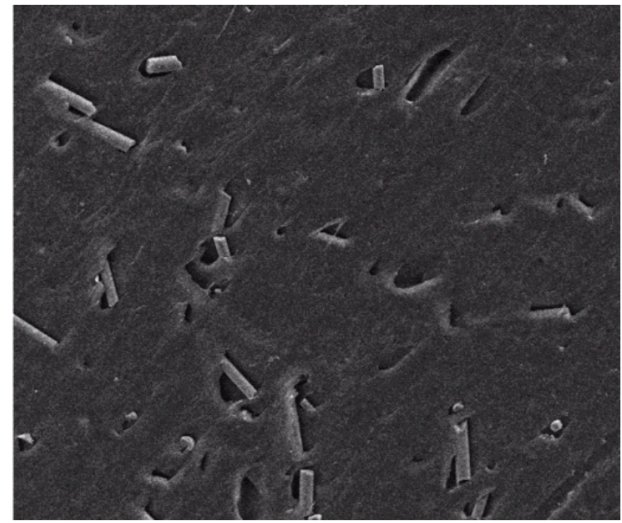

Fig. 5. SEM of the product of scheme 6

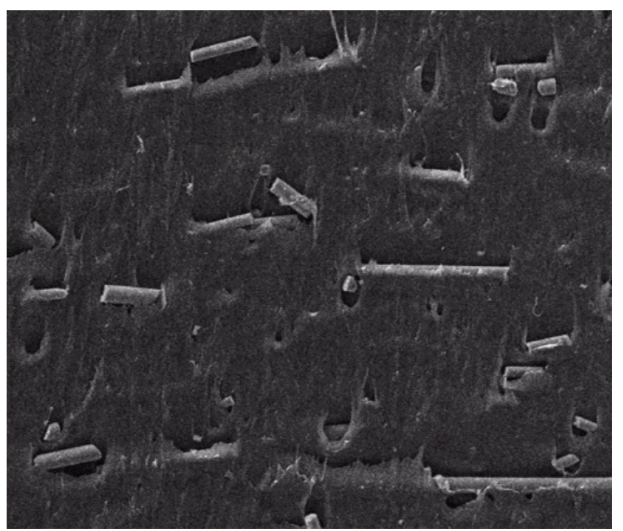

Fig. 6. SEM of the product of optimal scheme

phology of the fillers in both scheme 6 and optimal scheme.

The scanning electron micrographs were shown in Fig.5 and Fig.6, in which fillers in optimal scheme showing the parallel arrangement in Fig.6, while fillers in scheme 6 showing the disordered arrangement in Fig.5. When filling time and cooling time didn't change, the higher melting temperature, the lower viscosity, and the better mobility, thus degrees of freedom of the fillers were increased, that was the reason why fillers in scheme 6 showing the disordered arrangement. Disordered fillers decreased the impact strength of the product, and ordered fillers increased the impact strength of the product.

\section{Conclusions}

By orthogonal experiment method and response surface methodology, injection process parameters can be effectively analyzed and optimized, and obtained product with good impact performance. During the injection molding process, melting temperature, filling time and packing time have an interaction and cooperation effect on the impact performance. The result shows that, the impact performance can be increased by improving the arrangement of the fillers.

\section{Acknowledgements}

This work was financially supported by the Fundamental Research Funds for Nanjing Polytechnic Institute (project number: NHKY2013-13)

\section{References}

1. Lei Chen, Donghe Du, ; Sun, Kuan, ACS Appl. Mater. Interfaces, 24, 22334, 2014.

2. W Kim, J. W. Bae, I.D. Choi, Polym.Eng.Sci. 39, 756, 1999

3. M.C. Li, Y. Zhang, U. Cho, Mater. Design, 63, 565,2014

4. M.C. Li, X. Ge, U. Cho, Macromol.Res., 21, 793, 2013.

5. M. D. Azaman, S. M. Sapuan, S. Sulaiman, $M a-$ ter. Design, 52, 1018, 2013.

6. Marcin Wegrzyn, Sara Juan, Adolfo Benedito, $J$. Appl. Polym. Sci., 130, 2152, 2013

7. Yingjie Xu, QingWen Zhang, Weihong Zhang, Int. J. Advan. Manufactur. Techn., 76, 2199, 2015.

8. E. Ilinca, J.F. Hetu, D. Pelletier, Int. Polym. Proc., 20, 86, 2015.

9. Tong Wen, Xia Chen, Chen Yang, Chinese J. Polym. Sci., 32, 1535, 2014.

10. Ding Yang, Peng Zhao, Huamin Zhou, J. Reinf. Plast. Comp., 33, 1403, 2014.

11. Chung-Feng Jeffrey Kuo, ; Huang, Su ChangChiun, Fibers Polym., 15, 2597, 2014.

12. Chorng-Jyh Tzeng, Yung-Kuang Yang, MingHua Hsieh, Polym-plast. Technol. Eng., 50, 552, 2011.

13. Rajib Pal, Samrat Mukhopadhyay, Dipayan Das, Indian J. Fibre. Text. Res. 37, 11, 2012.

14. Chorng-Jyh Tzeng, Yung-Kuang Yang, Yu-Hsin Lin, Chih-Hung Tsai, Int. J. Adv. Manuf. Technol., 63, 691, 2012. 